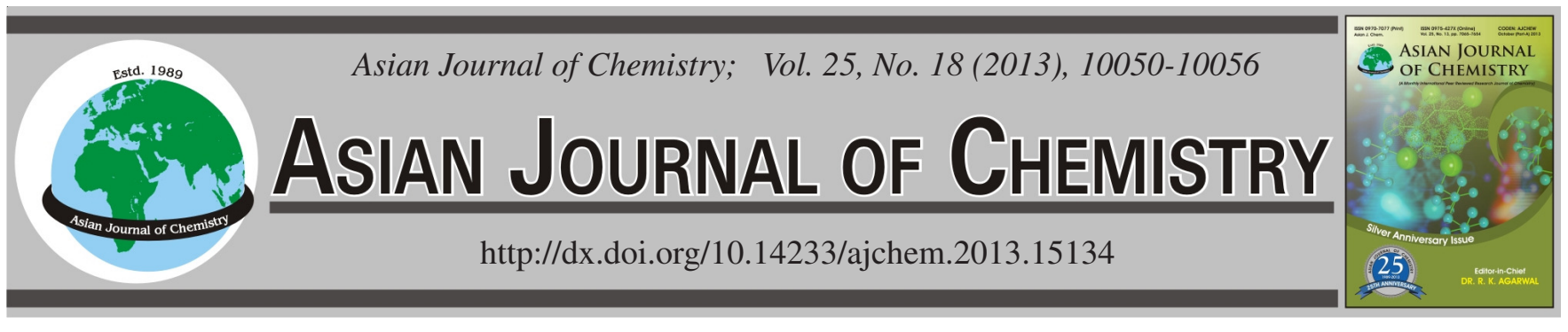

\title{
Performance of Purifying Synthetic High-Strength Chemical Fertilizer Wastewater by Earthworm Eco-Filter System
}

\author{
P. $\mathrm{CHENG}^{1}$, Z.G. GE, ${ }^{2, *}$ Y.J. ZHAO ${ }^{2, *}$, C. YAN ${ }^{3}$ and C.W. $\mathrm{Hu}^{4}$
}

${ }^{1}$ Department of Animal Husbandry Engineering, Zhengzhou College of Animal Husbandry Engineering, Zhengzhou 450011, P.R. China
${ }^{2}$ College of Biological, Chemical Science and Engineering, Jiaxing University, Jiaxing 314001, P.R. China
${ }^{3}$ Department of Environmental Science and Engineering, Fudan University, Shanghai 200433, P.R. China
${ }^{4}$ Shandong Provincial Key Laboratory of Water and Soil Conservation \& Environmental Protection, Linyi University, Linyi 276005, P.R. China

*Corresponding author: Tel/Fax: +86 576 83647467; E-mail: zyjun2007@163.com; squirre181@126.com

\begin{abstract}
Agricultural wastewater pollution has attracted increasing interest over the past decades owing to its significant effects on water quality. The agricultural wastewater coming from chemical fertilizers is a typical high-strength wastewater. The earthworm eco-filter is a potentially useful method for chemical fertilizer wastewater treatment. The performance and temporal variation of four different kinds of earthworm eco-filter systems in response to high carbon and high nitrogen loadings were analyzed in this research. The four kinds of earthworm eco-filter systems all exhibited high nutrient removal efficiencies under various high-strength loading treatments and the optimum earthworm eco-filter system was the earthworm eco-filter system with earthworms and plants. Relatively higher nutrient removal efficiency was achieved in summer (July, August and September) after increasing in spring (March, April and June). However, it decreased quickly during autumn (October and November) and winter (December and January). The best removal effect was obtained in August. The removal efficiencies of chemical oxygen demand, total nitrogen and total phosphorus were only significantly affected $(p<0.05)$ by season, system variation and their combined effects.
\end{abstract}

Key Words: High carbon loading, High nitrogen loading, COD removal, Total nitrogen removal, Total phosphorus removal.

\section{INTRODUCTION}

Agricultural wastewater pollution has attracted increasing interest over the past decades owing to its significant effects on water quality ${ }^{1}$. Grizzetti et al. ${ }^{2}$ and Kronvang et $a l .^{3}$ reported that agricultural wastewater has become the principal source of non-point source pollution, which can greatly cause surface-water eutrophication and groundwater nitrate enrichment ${ }^{2}$. Carbon, nitrogen and phosphorus in chemical fertilizers are important nutrient elements for the growth of crops. Optimal supply of chemical fertilizers can lead to good growth; however, excess in optimal supply could lead to excessive loss in nutrient loading, which can be a serious threat to water bodies ${ }^{4}$. In fact, agricultural wastewater coming from chemical fertilizers is a typical high-strength wastewater.

Overuse of $\mathrm{C}, \mathrm{N}$ and $\mathrm{P}$ chemical fertilizers in agriculture due to rapidly increasing demands by growing human population for crops and animal-derived food is a very serious concern in China ${ }^{1,4}$. In China, crop production has significantly increased since the 1980s mainly because of the increase usage of chemical fertilizers ${ }^{4}$. Zhen et al. ${ }^{5}$ reported that the average amount of $\mathrm{N}$ chemical fertilizer application for the winter wheat-summer maize double cropping system in the North China Plain increased nearly five times in the past 30 years. The overuse of chemical fertilizers has dramatically triggered many environmental problems. In some grain-producing areas in North China, the irrational application of $\mathrm{C}, \mathrm{N}$ and $\mathrm{P}$ chemical fertilizers has led to $\mathrm{N}$ enrichment in groundwater, as well as to eutrophication of surface water ${ }^{6}$. Wang et al. ${ }^{7}$ indicated that the mean value of the total annual $\mathrm{N}$ chemical fertilizer losses was as high as $243 \mathrm{~kg} \mathrm{~N} \mathrm{ha}^{-1}$ in the Sichuan Province of West China. Wang ${ }^{8}$ and Wang et al. ${ }^{7}$ also reported similar results, which suggested that $33-70 \%$ of $\mathrm{N}$ pollution and $30-73 \%$ of $\mathrm{P}$ pollution come from agricultural wastewater pollution in the Chaohu Lake, Taihu Lake and Dianchi Lake areas, which mainly came from chemical fertilizers. Compared with foreign countries, the overuse of chemical fertilizers in agriculture in China is extremely widespread. In 1997, China consumed $30 \%$ of the total chemical fertilizers in the world, whereas its farmland consumed only $7 \%$. Thus, identifying an optimum biosystem to treat this high-strength wastewater that comes from agricultural chemical fertilizers is very 
necessary. Although many studies have been conducted on the analysis framework and modeling tool to estimate the nutrient release from agricultural and rural activities, as well as to treat heavy metals and radionuclides in chemical fertilizers. Literature about the treatment of $\mathrm{C}, \mathrm{N}$ and $\mathrm{P}$ nutrients in chemical fertilizer wastewater is scarcely available ${ }^{1,10}$.

Considering economic conditions and farmland occupancy, conventional centralized wastewater treatment reactors, mainly based on upflow anaerobic sludge blankets or packed-bed biofilms, are not suitable for high-strength chemical fertilizer wastewater because the construction costs of collection and treatment facilities are quite high ${ }^{11,12}$. Furthermore, the constructed wetlands and stabilization ponds both require a considerable land area, obviously impossible in most countryside in China ${ }^{13}$. Meanwhile, earthworm eco-filter (EE) system has attracted increasing interest as an alternative for high-strength chemical fertilizer wastewater treatment because of its costeffectiveness, high removal efficiency and freedom from spatial restrictions ${ }^{12,14}$. In fact, earthworm eco-filters have already achieved success in their application in rural areas in China ${ }^{14}$. Therefore, earthworm eco-filter is a potentially useful method for chemical fertilizer wastewater treatment ${ }^{14}$. However, only a limited literature regarding the purification of high-strength chemical fertilizer wastewater by earthworm eco-filter is available. Although many works have been done on the performance of earthworm eco-filter in treating domestic sewage, as well as its related operating and design factors that contribute to high nutrient removal efficiency of nutrient contaminants. Furthermore, the combined processes of plants and filter substrates, as well as the activities of earthworms and their synergetic effects on microbes, significantly affect the removal efficiency of pollutants ${ }^{12}$. Zhao et al ${ }^{14}$ suggested that the key to efficient biological wastewater treatment using earthworm eco-filters relies on the knowledge on plants and earthworms and their responses to various influent nutrient loadings.

Therefore, this research focused on the effects of earthworm eco-filter combination of earthworms and plants on synthetic high-strength chemical fertilizer wastewater treatment under various influent pollution loadings in one growing season. Furthermore, major operational factors of the removal efficiency of the different earthworm eco-filter systems were investigated and optimal operational parameters were identified. The treatment performance responses of different earthworm eco-filter combinations were also determined to predict and explain the performance of an operational earthworm eco-filter system.

\section{EXPERIMENTAL}

Fig. 1 shows the schematic diagram of an earthworm eco-filter system, which is $40 \mathrm{~cm}$ long, $40 \mathrm{~cm}$ wide and $60 \mathrm{~cm}$ deep and made of Plexiglas ${ }^{14}$. A peristaltic pump was utilized to deliver synthetic chemical fertilizer wastewater from a plastic cistern to the earthworm eco-filter via a rotating water distributor, made of a $30 \mathrm{~cm}$-long PVC pipe with a diameter of $5 \mathrm{~cm}$ and with five $2 \mathrm{~mm}$-diameter holes equably distributed along its length. A sampling port is located at the bottom of the earthworm eco-filter.

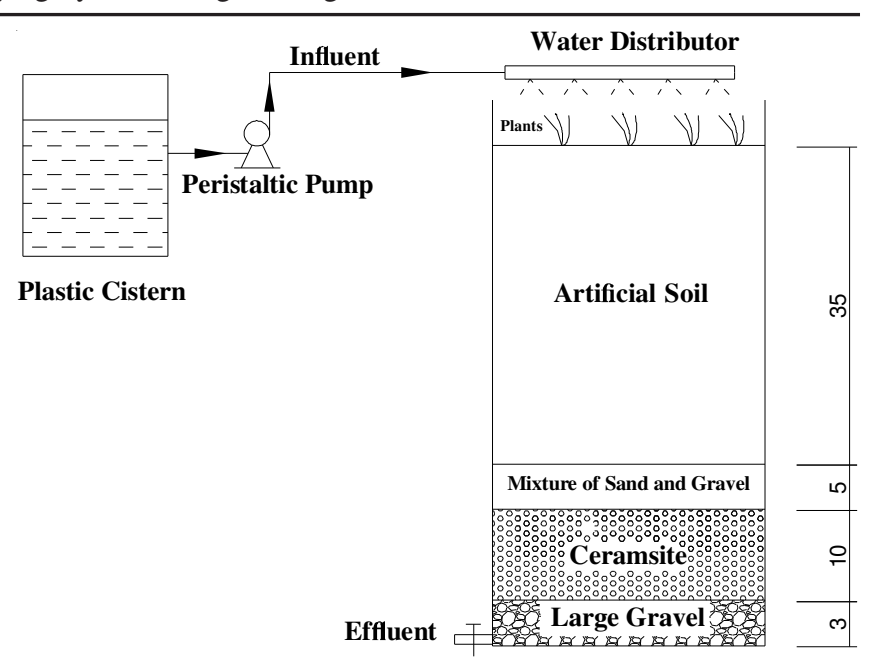

Fig. 1. Schematic diagram of earthworm eco-filter system (unit: $\mathrm{cm}$ )

The sequential layers of the earthworm eco-filter substrates from the bottom to the top were as follows: large gravel (diameter of 35-45 $\mathrm{mm}$ and height of $3 \mathrm{~cm}$ ), ceramsite (diameter of 20-40 mm and height of $10 \mathrm{~cm}$ ), a mixture (height $5 \mathrm{~cm}$ ) of sand (diameter of 0-1 mm) and gravel (diameter of 1-5 mm) and artificial soil (height $35 \mathrm{~cm}$ ), which was a mixture with a ratio of 99:1 (by weight) of peat soil and wood chips ${ }^{13,14}$. The peat soil was purchased from the Institute of Soil Science, Chinese Academy of Sciences. The wood chips, with sizes ranging from $1-3 \mathrm{~cm}^{2}$, were purchased from a local furniture factory. Four types of similarly constructed earthworm ecofilter systems were characterized as follows: without earthworms and plants (CK), with earthworms but without plants (E), without earthworms but with plants $(\mathrm{P})$ and with earthworms and plants (EP). Each type was prepared in octuplicate and every four of each replicant were, respectively fed with synthetic high $\mathrm{C}$ or high $\mathrm{N}$ loading wastewater.

Synthetic high-strength wastewater: For health and safety reasons, as well as for comparison with parallel experiments, synthetic high-strength (high $\mathrm{C}$ or high $\mathrm{N}$ loading) wastewater was used for the simulation of chemical fertilizer wastewater. It was a modification of OECD standard wastewater $^{15}$. For the high $\mathrm{C}$ loading treatment, the composition was $600 \mathrm{~g} \mathrm{~m}^{-3}$ glucose, $100 \mathrm{~g} \mathrm{~m}^{-3}$ carbamide, $15 \mathrm{~g} \mathrm{~m}^{-3} \mathrm{NaH}_{2} \mathrm{PO}_{4}$, $1.5 \mathrm{~g} \mathrm{~m}^{-3} \mathrm{KH}_{2} \mathrm{PO}_{4}, 4 \mathrm{~g} \mathrm{~m}^{-3} \mathrm{CaCl}_{2}$ and $2 \mathrm{~g} \mathrm{~m}^{-3} \mathrm{MgSO}_{4}$. The composition was $200 \mathrm{~g} \mathrm{~m}^{-3}$ glucose, $300 \mathrm{~g} \mathrm{~m}^{-3}$ carbamide, 15 $\mathrm{g} \mathrm{m}^{-3} \mathrm{NaH}_{2} \mathrm{PO}_{4}, 1.5 \mathrm{~g} \mathrm{~m}^{-3} \mathrm{KH}_{2} \mathrm{PO}_{4}, 4 \mathrm{~g} \mathrm{~m}^{-3} \mathrm{CaCl}_{2}$ and $2 \mathrm{~g} \mathrm{~m}^{-3}$ $\mathrm{MgSO}_{4}$ for the high $\mathrm{N}$ loading treatment. The characteristics of the influent synthetic wastewater are shown in Table-1.

Procedure: The earthworm eco-filter system adopted in this study was operated outdoors in Zhengzhou, People's Republic of China, 344' $36^{\prime \prime}$ N 11338'15" E. The environmental conditions in the experimental location are shown in Table-2. The earthworms-Eiseniafetida (Ohira 2nd)-used in this research were purchased from Minlong Earthworm Farm, Jinhua City, Zhejiang Province. The E and EP systems were both inoculated with $250 \mathrm{~g}$ of Eiseniafetida (Ohira 2nd) in the artificial soil layers with an initial earthworm density of 4.63 $\mathrm{g} \mathrm{L}^{-1}$ on February 1, 2011. The P and EP systems were also planted with Herba Scirpi Tabernaemontani $(15.37 \pm 2.15 \mathrm{~cm}$ tall), using four stems per earthworm eco-filter, on February 


\begin{tabular}{|c|c|c|c|c|c|c|}
\hline \multicolumn{7}{|c|}{$\begin{array}{l}\text { TABLE-1 } \\
\text { MEAN CONCENTRATIONS } \pm \text { SD OF INFLUENT WASTEWATER AND NUTRIENT REMOVAL EFFICIENCIES. } \\
\text { VALUES WITH DIFFERENT SUPERSCRIPT LETTERS IN THE SAME ROW ARE SIGNIFICANTLY DIFFERENT } \\
\text { AT } p=0.05 \text { ACCORDING TO DUNCAN'S MULTIPLE RANGE TESTS }\end{array}$} \\
\hline \multirow{2}{*}{\multicolumn{2}{|c|}{ Items }} & \multirow{2}{*}{$\begin{array}{l}\text { Influent } \\
\left(\mathrm{mg} \mathrm{L}^{-1}\right)\end{array}$} & \multicolumn{4}{|c|}{ Removal efficiency $(\%)$} \\
\hline & & & CK & $\mathrm{E}$ & $\mathrm{P}$ & EP \\
\hline \multirow{3}{*}{ High C loading } & COD & $603.15 \pm 4.32$ & $57.24^{\mathrm{c}} \pm 10.52$ & $65.94^{b} \pm 9.19$ & $74.92^{b} \pm 11.37$ & $86.45^{\mathrm{a}} \pm 11.58$ \\
\hline & $\mathrm{TN}$ & $50.36 \pm 1.09$ & $43.77^{c} \pm 9.64$ & $47.17^{\mathrm{bc}} \pm 11.30$ & $50.76^{\mathrm{b}} \pm 8.35$ & $55.13^{\mathrm{ab}} \pm 10.43$ \\
\hline & $\mathrm{TP}$ & $5.03 \pm 1.12$ & $45.01^{\mathrm{c}} \pm 11.35$ & $55.24^{\mathrm{b}} \pm 10.43$ & $61.62^{\mathrm{ab}} \pm 12.54$ & $69.16^{\mathrm{a}} \pm 9.68$ \\
\hline \multirow{3}{*}{ High $\mathrm{N}$ loading } & COD & $201.42 \pm 3.56$ & $51.82^{\mathrm{c}} \pm 8.35$ & $63.65^{\mathrm{b}} \pm 8.54$ & $68.56^{\mathrm{b}} \pm 10.91$ & $76.43^{a} \pm 11.73$ \\
\hline & $\mathrm{TN}$ & $150.92 \pm 5.47$ & $47.41^{c} \pm 9.56$ & $54.65^{\text {bc }} \pm 9.53$ & $59.06^{\mathrm{b}} \pm 11.33$ & $71.72^{\mathrm{ab}} \pm 10.84$ \\
\hline & $\mathrm{TP}$ & $5.18 \pm 0.93$ & $54.75^{\mathrm{c}} \pm 7.34$ & $62.70^{\mathrm{b}} \pm 11.83$ & $68.72^{\mathrm{ab}} \pm 10.48$ & $76.62^{\mathrm{a}} \pm 9.26$ \\
\hline
\end{tabular}

\begin{tabular}{ccccccccccccc}
\multicolumn{10}{c}{ TABLE-2 } \\
& \multicolumn{10}{c}{ ENVIRONMENTAL CONDITIONS OF EXPERIMENTAL LOCATION. (T-AVERAGE } \\
& TEMPERATURE, RH - RELATIVE HUMIDITY, WS - AVERAGE WIND SPEED) \\
\hline Items & Feb & Mar & Apr & May & Jun & Jul & Aug & Sep & Oct & Nov & Dec & Jan \\
\hline T $\left({ }^{\circ} \mathrm{C}\right)$ & 10.7 & 14.3 & 17.3 & 20.6 & 24.1 & 32.7 & 39.6 & 33.2 & 28.4 & 18.1 & 11.5 & 8.4 \\
RH $(\%)$ & $53-58$ & $51-63$ & $58-64$ & $62-70$ & $68-84$ & $71-85$ & $73-91$ & $64-70$ & $61-68$ & $52-57$ & $42-50$ & $38-54$ \\
WS $\left(\mathrm{m} \mathrm{s}^{-1}\right)$ & 3.2 & 3.1 & 3.2 & 3.3 & 3.2 & 3.0 & 3.4 & 3.2 & 2.9 & 3.1 & 2.9 & 3.3 \\
\hline
\end{tabular}

1, 2011. Before the introduction of influent wastewater, all earthworm eco-filter system sets were flooded with tap water for one month (February 1-28) for the acclimatization of earthworms and plants, as well as for the colonization and accumulation of microorganisms in the systems. The formal experimental period was from March 1, 2011 to January 31, 2012. The operating period was 9:00 AM to 3:00 PM daily at a flow rate of $8.0 \times 10^{-3} \mathrm{~m}^{3} \mathrm{~h}^{-1}$. The hydraulic surface loading of the wastewater was maintained at $0.3 \mathrm{~m}^{3} \mathrm{~m}^{-2} \mathrm{~d}^{-1}$ The wet to dry time ratio was maintained at 1:3. The sampling and monitoring of earthworm eco-filters were conducted at 8:00 AM every Monday. The mean values of every earthworm eco-filter sample over four weeks in one month were used to calculate the removal efficiency of each parameter.

Water quality analyses: Chemical oxygen demand (COD), total nitrogen (TN) and total phosphorus (TP) were analyzed using the methods described in APHA-AWWA$\mathrm{WPCF}^{16}$. The dissolved oxygen (DO) and the temperature were measured using an Orion DO Probe (Model 862Aplus, USA). The oxidation-reduction potential (ORP) and $\mathrm{pH}$ were recorded using Orion 250Aplus ORP Field Kit and Portable pH Meter (Model 250Aplus, USA), respectively. The nutrient removal efficiency was calculated as:

$$
\mathrm{R}=\left(1-\frac{\mathrm{C}_{\mathrm{e}}}{\mathrm{C}_{\mathrm{i}}}\right) \times 100
$$

where $\mathrm{R}$ (in \%) is the removal efficiency and $\mathrm{C}_{\mathrm{i}}$ and $\mathrm{C}_{\mathrm{e}}$ (in $\mathrm{mg}$ $\mathrm{L}^{-1}$ ) are the influent and effluent concentrations.

Statistical analyses: The SPSS software was utilized to analyze all statistics ${ }^{17}$. One-way ANOVA was used to test the differences among the related parameters of the four types of earthworm eco-filter systems under the same influent conditions. Two-way ANOVA was used to test the differences in the effects of various influent high-strength wastewater treatments, earthworm eco-filter system variation, seasons and interaction on the performance of two of these treatments. Three-way ANOVA was used to test the differences in the effects of the interaction of various influent high-strength wastewater treatments, earthworm eco-filter system variation and seasons on the treatment performance. Duncan's multiple range tests were used to assess further the differences among the earthworm eco-filter systems that were significant in the ANOVA.

\section{RESULTS AND DISCUSSION}

Physico-chemical variations: The physico-chemical variations of the influent and effluent wastewater in the earthworm eco-filter system are shown in Table-3. The influent DO values were significantly higher $(p<0.05)$ than those under high $\mathrm{C}$ or high $\mathrm{N}$ loading. However, the influent $\mathrm{DO}$ values were significantly lower $(p<0.05)$ in $\mathrm{CK}$ and $\mathrm{E}$ than those in $\mathrm{P}$ and $\mathrm{EP}$ at high $\mathrm{C}$ loading, whereas no significant differences

\begin{tabular}{|c|c|c|c|c|c|c|}
\hline \multicolumn{7}{|c|}{$\begin{array}{l}\text { MEAN CONCENTRATIONS } \pm \text { SD OF PHYSICO-CHEMICAL FACTORS. VALUES WITH DIFFERENT SUPERSCRIPT LETTERS } \\
\text { IN THE SAME ROW ARE SIGNIFICANTLY DIFFERENT AT } p=0.05 \text { ACCORDING TO DUNCAN'S MULTIPLE RANGE TESTS }\end{array}$} \\
\hline \multirow{2}{*}{\multicolumn{2}{|c|}{ Items }} & \multirow{2}{*}{ Influent } & \multicolumn{4}{|c|}{ Effluent } \\
\hline & & & CK & $\mathrm{E}$ & $\mathrm{P}$ & EP \\
\hline \multirow{4}{*}{ High C loading } & $\mathrm{DO}\left(\mathrm{mg} \mathrm{L}^{-1}\right)$ & $4.02^{\mathrm{a}} \pm 0.53$ & $1.69^{c} \pm 0.25$ & $1.73^{\mathrm{c}} \pm 0.61$ & $2.53^{\mathrm{b}} \pm 0.36$ & $2.61^{\mathrm{b}} \pm 0.49$ \\
\hline & $\mathrm{ORP}(\mathrm{mV})$ & $61.32^{\mathrm{a}} \pm 4.27$ & $54.94^{\mathrm{b}} \pm 3.97$ & $50.85^{\mathrm{b}} \pm 4.45$ & $56.82^{\mathrm{b}} \pm 4.79$ & $58.45^{\mathrm{b}} \pm 4.54$ \\
\hline & $\mathrm{pH}$ & $7.48^{\mathrm{a}} \pm 0.19$ & $7.36^{\mathrm{b}} \pm 0.43$ & $7.35^{\mathrm{b}} \pm 0.53$ & $7.40^{\mathrm{b}} \pm 0.25$ & $7.32^{\mathrm{b}} \pm 0.38$ \\
\hline & $\mathrm{T}\left({ }^{\circ} \mathrm{C}\right)$ & $26.3^{\mathrm{a}} \pm 8.2$ & $25.2^{\mathrm{a}} \pm 9.4$ & $25.4^{\mathrm{a}} \pm 7.5$ & $25.3^{\mathrm{a}} \pm 8.2$ & $25.7^{\mathrm{a}} \pm 9.3$ \\
\hline \multirow{4}{*}{ High $\mathrm{N}$ loading } & $\mathrm{DO}\left(\mathrm{mg} \mathrm{L}^{-1}\right)$ & $4.16^{\mathrm{a}} \pm 0.72$ & $1.61^{b} \pm 0.42$ & $1.69^{b} \pm 0.31$ & $1.73^{b} \pm 0.25$ & $1.83^{\mathrm{b}} \pm 0.74$ \\
\hline & ORP (mv) & $67.24^{a} \pm 4.94$ & $55.32^{b} \pm 3.56$ & $60.23^{b} \pm 4.27$ & $59.43^{b} \pm 3.68$ & $59.35^{\mathrm{b}} \pm 4.64$ \\
\hline & $\mathrm{pH}$ & $7.50^{a} \pm 0.86$ & $7.31^{\mathrm{b}} \pm 0.42$ & $7.39^{\mathrm{b}} \pm 0.53$ & $7.38^{b} \pm 0.12$ & $7.35^{\mathrm{b}} \pm 0.24$ \\
\hline & $\mathrm{T}\left({ }^{\circ} \mathrm{C}\right)$ & $26.6^{\mathrm{a}} \pm 9.1$ & $25.3^{\mathrm{a}} \pm 7.0$ & $25.1^{\mathrm{a}} \pm 9.2$ & $25.6^{\mathrm{a}} \pm 9.1$ & $25.7^{\mathrm{a}} \pm 7.2$ \\
\hline
\end{tabular}


$(p>0.05)$ between CK and E or P and EP were detected. No significant differences $(p>0.05)$ among the effluent $\mathrm{DO}$ values of the four types of earthworm eco-filters at high $\mathrm{N}$ loading were observed, but DO values in P and EP were still slightly higher than those in $\mathrm{CK}$ and $\mathrm{E}$. The variation results of the ORP values under high $\mathrm{C}$ and high $\mathrm{N}$ loadings were similar. The effluent ORP values were significantly lower than the influent ORP values $(p<0.05)$, but no significant differences ( $p>0.05$ ) were found among the four types of earthworm eco-filters. In both high $\mathrm{C}$ and high $\mathrm{N}$ loading treatments, the $\mathrm{pH}$ values were significantly lower $(p<0.05)$ in the effluent of the four types of earthworm eco-filters than those in the influent. No significant differences $(p>0.05)$ were detected among the four types of earthworm eco-filters. The temperature did not change significantly under both high $\mathrm{C}$ and high $\mathrm{N}$ loading treatments and no significant differences $(p>0.05)$ were observed between the influent and effluent, as well as among the effluent values of the four types of earthworm eco-filters. These results agreed well with the results of Zhao et $a l .{ }^{14}$.

Nutrient removal efficiency: Table- 1 shows the removal efficiencies of the four types of earthworm eco-filters under high $\mathrm{C}$ and high $\mathrm{N}$ loading treatments. The variation trends of the removal efficiencies of COD, total nitrogen and total phosphorus in various earthworm eco-filter systems were similar: $\mathrm{EP}>\mathrm{P}>\mathrm{E}>\mathrm{CK}$. The highest removal efficiencies of COD, total nitrogen and total phosphorus were $86.45 \pm 11.58,55.13$ \pm 10.43 and $69.16 \pm 9.68 \%$, respectively, under high $\mathrm{C}$ loading and $76.43 \pm 11.73,71.72 \pm 10.84$ and $76.62 \pm 9.26 \%$, respectively, under high $\mathrm{N}$ loading. These results agreed with the results of Zhao et al. ${ }^{14}$, which reported that the EP system always achieves the best nutrient removal efficiency.

The results of the COD removal efficiency of the various earthworm eco-filter systems for both high $\mathrm{C}$ and high $\mathrm{N}$ loading treatments were similar. The COD removal efficiency in CK was significantly lower $(p<0.05)$ than those in E and $\mathrm{P}$ (Table-1). These phenomena can be explained by the theory that earthworms and plants promote COD removal. Luth et al. ${ }^{18}$ and Zhao et al. ${ }^{14}$ suggested that earthworms play a significant role in the earthworm eco-filter system (e.g., E group in this research) because their activities are beneficial in assimilating and mixing organic matters, as well as in maintaining air permeability in the earthworm eco-filter substrates. Furthermore, earthworm eco-filters with aquatic plants ( $p$ group) can provide a good condition for microbe reproduction. In fact, aquatic plants, such as the Herba Scirpi Tabernaemontani is characterized by aerenchyma, which not only supplies adequate atmospheric oxygen but also permits root systems to function as some sorts of biological filters ${ }^{14}$. In addition, no significant differences $(p>0.05)$ between the $\mathrm{E}$ and $\mathrm{P}$ groups were detected (Table-1). This result indicated that earthworms and plants have the same contribution to COD removal. However, the COD removal efficiency of the EP group was significantly higher $(p<0.05)$ than those in the other three kinds of earthworm eco-filters (Table-1). This result can be explained by the theory that the earthworm eco-filter group that combined earthworms with plants produces synergetic effects. Loehr et al. ${ }^{19}$ suggested that organic matter removal process could be accelerated by the synergetic effects of aerobic microbe communities on the plant root zones and earthworms. Soluble organic materials coming from the metabolism of earthworms are preferentially and efficiently decomposed by aerobic microbes in the plant root zones ${ }^{20}$.

The EP group achieved the highest total nitrogen removal efficiency. It had significantly higher $(p<0.05)$ total nitrogen removal efficiencies than $\mathrm{CK}$ under various loading treatments (Table-1). These results agreed with the findings of Chiarawatchai and Nuengjamnong ${ }^{21}$ and Zhao et al. ${ }^{14}$. The synergetic effects played an important role because earthworms in the substrate can promote microbe reproduction in the rhizosphere. This process created the right environment for aerobic heterotrophic nitrogen mineralization bacterial communities in the earthworm eco-filter system ${ }^{21,22}$. Furthermore, the $p$ group had significantly higher $(p<0.05)$ total nitrogen removal efficiency than the CK group under various loading treatments (Table-1) because plant root zones developed an aerobic-anaerobic environment, characterized by the acceleration of the nitrification-denitrification process ${ }^{23}$. Nevertheless, no significant differences $(p>$ $0.05)$ in the total nitrogen removal efficiency was observed among the E, P and EP groups, as well as between the CK and $\mathrm{E}$ groups under both high $\mathrm{C}$ and high $\mathrm{N}$ loading treatments (Table-1). This finding indicated that plants contributed more to total nitrogen removal than earthworms, attributed to the theory that the nitrification-denitrification process, which supports the root system of plants, is predominant in the earthworm eco-filter system rather than the metabolism of earthworms $^{12,13}$.

The E group achieved significantly higher $(p<0.05)$ total phosphorus removal efficiencies than the $\mathrm{CK}$ group because the earthworms were able to absorbed phosphorus from wastewater. Subsequently, phosphorus nutrient transformation was achieved ${ }^{23}$. The $\mathrm{P}$ group achieved significantly higher $(p<0.05)$ total phosphorus removal efficiencies than the CK group, which indicated that plants, as well as microbes in the root systems, were able to uptake directly phosphorus as nutrient ${ }^{24}$. However, no significant differences $(p>0.05)$ between $\mathrm{E}$ and $\mathrm{P}(p>0.05)$ under high $\mathrm{C}$ or high $\mathrm{N}$ loading treatment were observed (Table-1). This result suggested that plants and earthworms in the earthworm eco-filter system had similar contributions to the total phosphorus removal. No significant differences $(p>0.05)$ were found between the P and EP groups, indicating that the effects of total phosphorus removal from wastewater on earthworm eco-filter systems with earthworms were modest ${ }^{14}$. These results agreed with the findings of Tomar and Suthar, which reported that total phosphorus removal in earthworm eco-filter systems mainly depends on the physical adsorption of sorption sites and ligand exchange reactions $\mathrm{s}^{20}$. Under both high $\mathrm{C}$ and high $\mathrm{N}$ loading treatments, the total phosphorus removal efficiency in EP was significantly higher $(p<0.05)$ than those in CK and E (Table-1). Zhao et al. ${ }^{14}$ stated that the symbiotic activities of earthworms and associated microflora in plant roots were responsible for this high total phosphorus removal efficiency. The aerobic microorganisms in the root system and the earthworms were able to act symbiotically to achieve efficiently the decomposition of phosphorus. Earthworm movements supplied sufficient oxygen via 
modification of soil aeration, which formed an oxygen-rich atmosphere in the soil layers and contributed to the physical adsorption of phosphorus in the substrates ${ }^{12,13}$.

Time course of nutrient removal: The COD removal efficiencies in the four types of earthworm eco-filter systems under various high-strength loadings exhibited similar fluctuations during the operating period (Fig. 2). In reference to the various earthworm eco-filter types, most of the COD removal efficiencies, except for the E type in October under high $\mathrm{C}$ and high $\mathrm{N}$ loading treatments, exhibited the sequence $\mathrm{EP}>\mathrm{P}>\mathrm{E}>\mathrm{CK}$. This result was due to the synergetic effects that resulted from the combination of earthworms and plants ${ }^{19}$. With respect to the time course, the COD removal efficiency was relatively higher in summer (July, August and September) under both high $\mathrm{C}$ and high $\mathrm{N}$ loading treatments (Fig. 2). Furthermore, the highest removal efficiency was achieved in August and decreased quickly in autumn (October and November) and winter (December and January). These results agreed with the findings of Zhao et al. ${ }^{14}$. The higher temperature in summer (Table-2) was conducive to plant growth, as well as to the microbial reproduction in the plant roots ${ }^{14}$. In addition, the high $\mathrm{C}$ loading treatment achieved similar removal efficiency compared with the high $\mathrm{N}$ loading treatment. Thus, the COD removal efficiencies were significantly affected $(p<$ $0.05)$ by season, system variation and their combined effects (Table-4).

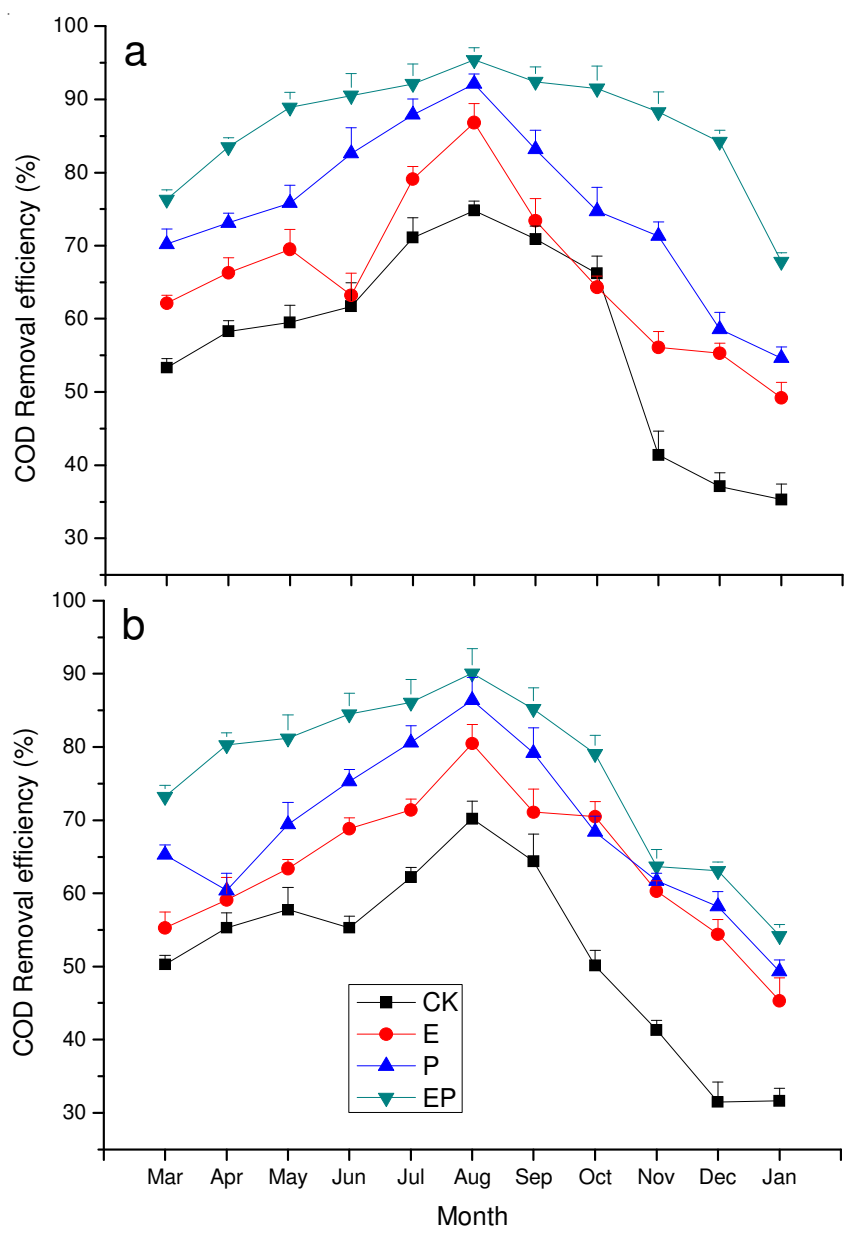

Fig. 2. COD removal efficiency of the earthworm eco-filter systems under (a) high $\mathrm{C}$ loading and (b) high $\mathrm{N}$ loading
TABLE-4

$p$-VALUES OF FACTORS AND THE COMBINED EFFECTS OF FACTORS FOR EACH PARAMETER UNDER FOUR TYPES OF EE SYSTEMS BASED ON ANALYSIS OF VARIANCE. LOADING VARIATION: HIGH C LOADING TREATMENT AND HIGH N LOADING TREATMENT; SYSTEM VARIATION: CK, E, P, AND EP; SEASON: FROM MARCH TO JANUARY; ${ }^{*} p<0.05, * * p<0.01$

\begin{tabular}{lccc}
\multirow{2}{*}{\multicolumn{1}{c}{ Factors }} & \multicolumn{3}{c}{ Nutrient removal efficiency $(\%)$} \\
\cline { 2 - 4 } & COD & TN & TP \\
\hline Loading variation & 0.069 & 0.127 & 0.343 \\
Season & $<0.0001^{* *}$ & $0.006^{*}$ & $0.013^{*}$ \\
System variation & $0.021^{*}$ & $0.042^{*}$ & $0.035^{*}$ \\
Loading variation $\times$ season & 0.057 & 0.083 & 0.142 \\
System variation $\times$ season & $0.024^{*}$ & $0.031^{*}$ & $0.048^{*}$ \\
Loading variation $\times$ system variation & 0.108 & 0.294 & 0.386 \\
System variation $\times$ loading & 0.243 & 0.323 & 0.247 \\
variation $\times$ season & & & \\
\hline
\end{tabular}

The removal efficiencies of total nitrogen in the earthworm eco-filter systems under high-strength loadings exhibited similar variation trends during the operating period (Fig. 3). Most of the total nitrogen removal efficiencies under various earthworm eco-filters demonstrated the following sequence: $\mathrm{EP}>\mathrm{P}>\mathrm{E}>\mathrm{CK}$. This result agreed with the COD removal efficiency, which can be explained by the theory that plant root zones and earthworm activity established an aerobicanaerobic environment that accelerates the nitrificationdenitrification process ${ }^{23}$. The total nitrogen removal efficiency was relatively higher in summer (July, August and September)

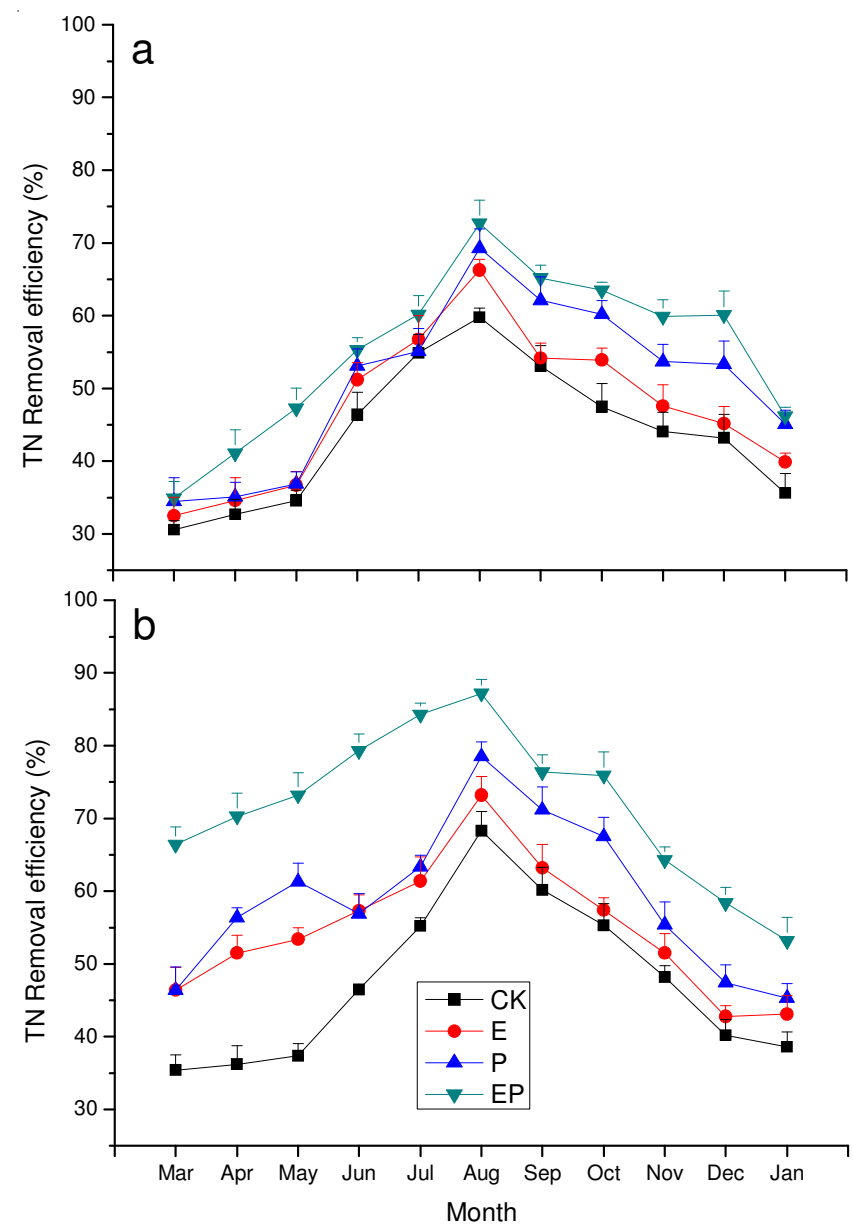

Fig. 3. Total nitrogen removal efficiency of the earthworm eco-filter systems under (a) high $\mathrm{C}$ loading and (b) high $\mathrm{N}$ loading 
under high $\mathrm{C}$ and high $\mathrm{N}$ loading treatments but decreased quickly during other seasons (Fig. 3). Zhao et al. ${ }^{14}$ reported similar results. These phenomena were due to the fact that season variation had a significant effect on total nitrogen removal. Nitrification depends strongly on temperature ${ }^{25}$. In the current research, higher temperature seasons (Table-2) were conducive to aquatic plant growth, whose specific tissues (aerenchyma) can make plant root systems provide a favourable aerobic-anaerobic environment. Simultaneous nitrificationdenitrification process was then conducted successfully ${ }^{26}$. In addition, higher temperature was also beneficial to the activity of denitrifying and nitrifying bacteria ${ }^{25}$. Furthermore, earthworm eco-filter systems under high $\mathrm{N}$ loading treatment maintained total nitrogen removal efficiency similar to high $\mathrm{C}$ loading treatment. These results were attributed to the theory that adequate organic carbon leads to high total nitrogen removal and the denitrification process largely depends on the amount of available organic carbon ${ }^{14}$. Therefore, the organic carbon source under the high $\mathrm{N}$ loading treatment was relatively insufficient. Thus, the total nitrogen removal efficiencies were significantly affected $(p<0.05)$ by season, system variation and their combined effects (Table-4).

The total phosphorus removal efficiencies in the earthworm eco-filter systems under various high-strength loadings exhibited similar variation trends (Fig. 4). All total nitrogen removal efficiencies in the various earthworm eco-filter systems

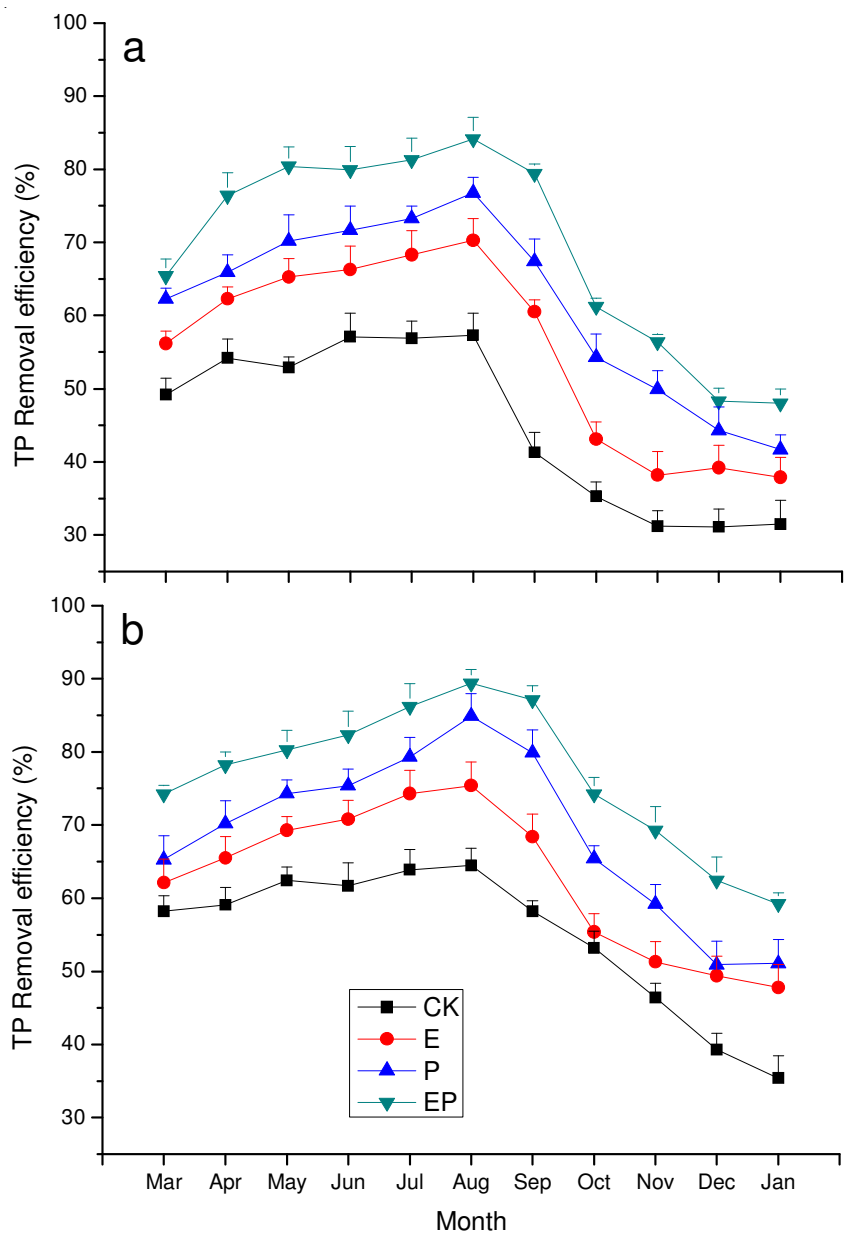

Fig. 4. Total phosphorus removal efficiency of the earthworm eco-filter systems under (a) high $\mathrm{C}$ loading and (b) high $\mathrm{N}$ loading demonstrated the following sequence: $\mathrm{EP}>\mathrm{P}>\mathrm{E}>\mathrm{CK}$. This result was consistent with the removal efficiencies of COD and total nitrogen, resulting from the symbiotic activities of earthworms and the associated microflora in plant roots, which were both able to promote rapid $\mathrm{P}$ mineralization in the earthworm eco-filter system ${ }^{14}$.

The total phosphorus removal efficiencies were relatively higher in spring (March, April, May and June) and summer (July, August and September) under high $\mathrm{C}$ and high $\mathrm{N}$ loading treatments and achieved the best removal effect in August. Then, the removal efficiencies decreased quickly in autumn (October and November) and winter (December and January). These results were in agreement with the variation trends of the environmental temperature in Table-1, suggesting that the removal efficiency of total phosphorus was affected by season variation. In fact, the improved purification effects of total phosphorus were achieved in summer because of higher temperatures (Table-4). Moreover, these results could be attributed to the theory that relatively higher temperatures benefit earthworm activity, plant growth and microbial reproduction ${ }^{12}$. These results were also in agreement with the data reported by Zhao et al. ${ }^{14}$. Furthermore, the total phosphorus removal efficiencies under high $\mathrm{N}$ and high $\mathrm{C}$ loading treatments were similar. These results demonstrated that the organic carbon and nitrogen sources did not significantly affect the total phosphorus removal process. Fang et al. ${ }^{12}$ and Zhao et al. ${ }^{14}$ reported the same results. Thus, total phosphorus removal efficiencies were significantly affected $(p<0.05)$ by season, system variation and the combined effect of season and system variation (Table-4).

\section{Conclusion}

Four kinds of earthworm eco-filter systems (CK, E, P and $\mathrm{EP})$ have demonstrated high nutrient removal efficiencies under various high-strength loading treatments and the optimum earthworm eco-filter system was the earthworm eco-filter system with earthworms and plants (EP group). Relatively higher nutrient removal efficiency was achieved in summer (July, August and September) after increasing in spring (March, April and June). However, it decreased quickly during autumn (October and November) and winter (December and January). Therefore, the best removal effect was obtained in August. The removal efficiencies of COD, total nitrogen and total phosphorus were only significantly affected $(\mathrm{P}<0.05)$ by season, system variation and their combined effects.

\section{ACKNOWLEDGEMENTS}

The authors thank colleagues and students from Zhengzhou University for maintaining the experimental systems during the research period. This study was sponsored by the Beijing Green Future Environment Foundation and Postdoctoral Foundation of China (2012M510790).

\section{REFERENCES}

1. M. Chen, J. Chen and F. Sun, Sci. Total Environ., 408, 5123 (2010).

2. B. Grizzetti, F. Bouraoui, G. de Marsily and G. Bidoglio, J. Hydrol., 304, 302 (2005).

3. B. Kronvang, N. Vagstad, H. Behrendt, J. Bogestrand and S.E. Larsen, Soil Use Manage., 23(S1), 104 (2007). 
4. L. Ma, G.L. Velthof, F.H. Wang, W. Qin, W.F. Zhang, Z. Liu, Y. Zhang, J. Wei, J.P. Lesschen, W.Q. Ma, O. Oenema and F.S. Zhang, Sci. Total Environ., 434, 51 (2012).

5. L. Zhen, M.A. Zoebisch, G.B. Chen and Z.M. Feng, J. Environ. Manage., 79, 409 (2006).

6. A.F. Bouwman, A.H.W. Beusen and G. Billen, Global Biogeochem. Cycles, 23, 11 (2009).

7. F.H. Wang, Z.X. Dou, L. Ma, W.Q. Ma, J.T. Sims and F.S. Zhang, J. Environ. Qual., 39, 1537 (2010).

8. X. Wang, Water Sci. Technol., 53, 1 (2006).

9. W.F. Sheldrick, J.K. Syers and J. Lingard, Agric. Ecosyst. Environ., 94, 341 (2003)

10. C.H. Mo, Q.Y. Cai, Y.H. Li and Q.Y. Zeng, J. Hazard. Mater., 152 , 1208 (2008).

11. F.H. Ye and Y. Li, Ecol. Eng., 35, 1043 (2009).

12. C.X. Fang, Z. Zheng, X.Z. Luo and F.H. Guo, Fresen. Environ. Bull., 19, 1099 (2010).

13. C.X. Fang, F.H. Guo, X.Z. Luo, J.Y. Chen and Z. Zheng, Fresen. Environ. Bull., 20, 235 (2011)

14. Y.J. Zhao, Z. Hui, X. Chao, E. Nie, H.J. Li, J. He and Z. Zheng, Ecol. Eng., 37, 1546 (2011).

15. Guidelines for Testing of Chemicals Simulation Test-Aerobic Sewage Treatment. Technical Report, Organisation for Economic Co-operation and Development (OECD), 1996, OECD, Paris, p. 3/52-3/83 (1996).
16. Standard Methods for The Examination of Water and Wastewater, APHA-AWWA-WPCF, 1995, American Public Health Association, Washington, DC, p. 4/100-4/246 (1995).

17. Analytical Software, SPSS, 2003, SPSS Inc., Chicago, pp. 2/14-2/97 (2003).

18. Luth, P. Robin, P. Germain, M. Lecomte, B. Landrain, Y. Li and D. Cluzeau, Bioresour. Technol., 102, 3679 (2011).

19. T.C. Loehr, Y.C. Lee, J.B. Liang and D. Tan, in eds.: C.A. Edwards and E.F. Neuhauser, Stabilization of Liquid Municipal Sludge Using Earthworms, In: Earthworms in Waste and Environmental Management, SPB, Academic Pub., The Hague, pp. 1/95-1/110 (1988).

20. P. Tomar and S. Suthar, Desalination, 282, 95 (2011).

21. N. Chiarawatchai and C. Nuengjamnong, Thai. J. Vet. Med., 39, 157 (2009).

22. A. Ghani, M. Dexter and K.W. Perrott, Soil Biol. Biochem., 35, 1231 (2003).

23. L.E. de-Bashan and Y. Bashan, Water Res., 38, 4222 (2004).

24. B. Wen, Y. Liu, X.Y. Hu and X.Q. Shan, Chemosphere, 63, 1179 (2006).

25. A.G. Werker, J.M. Dougherty, J.L. McHenry and W.A. van Loon, Ecol. Eng., 19, 1 (2002).

26. G. Langergraber, K. Leroch, A. Pressl, K. Sleytr, R. Rohrhofer and R. Haberl, Desalination, 246, 55 (2009). 